\title{
Language Learning Strategies Employed by Chinese English-Major Pre-Service Teachers in Relation to Gender and Personality Types
}

\author{
Chaoying Zhou ${ }^{1} \&$ Channarong Intaraprasert ${ }^{1}$ \\ ${ }^{1}$ School of Foreign Languages, Institute of Social Technology, Suranaree University of Technology, Thailand \\ Correspondence: Chaoying Zhou, School of Foreign Languages, Institute of Social Technology, Suranaree \\ University of Technology, 111 University Avenue, Muang District, Nakhon Ratchasima 30000, Thailand. E-mail: \\ cathyzhou999@sina.com
}

Received: September 30, 2014 Accepted: October 30, 2014 Online Published: December 17, 2014

doi:10.5539/elt.v8n1p155 URL: http://dx.doi.org/10.5539/elt.v8n1p155

\begin{abstract}
This study was intended to investigate the use of language learning strategy employed by English-major pre-service teachers in Midwest China in relation to their gender and personality types. The modified Strategy Inventory for Language Learning (SILL) and adopted personality type inventory were used to collect the data. ANOVA and Chi-square tests were performed for data analysis. The results revealed that gender and personality types have some effects on pre-service teachers' strategy use at the overall, category and individual levels. The variation patterns of the strategy use were found in terms of the two variables. The implications of these findings for ESL teaching and learning were also discussed.
\end{abstract}

Keywords: language learning strategies, gender, personality types, extroversion-introversion scale, judging-perceiving scale

\section{Introduction}

In the field of L2 acquisition, language learning strategies (LLSs) have been considered to be a key variable in the study of individual differences (Skehan, 1989; Oxford, 1990; Dörnyei, 2005). Oxford (1990, p. 1) states that strategies are "especially important for language learning because they are tools for active, self-directed involvement, which is essential for developing communicative competence. Appropriate LLSs result in improved proficiency and greater self-confidence". According to Chang, Liu and Lee (2007), researchers believe that LLSs play significant roles in L2/FL learning, due to the fact that LLSs can help learners to facilitate the acquisition, storage, retrieval or use of information and increase self-confidence. Students use learning strategies to learn a wide range of subjects, from native language reading to new languages. Different language learners using different learning strategies result in successful and unsuccessful language learners.

Research on LLSs have been going on over 30 years and have made great achievements and contributions to theories on strategies and L2 acquisition. Early research on LLSs focuses more on good language learner studies (e.g. Rubin, 1975; Stern, 1975; Naiman et al., 1978). Then many researchers show their interest in factors influencing choice of LLSs (e.g. Chamot \& O’Malley, 1987; Oxford \& Nyikos, 1989; Ehrman, 1990; El-Dib, 2004; Hong-Nam \& Leavell, 2006; Kavasoglu, 2009; Radwan, 2011), and in relationship among LLSs, some variables of individual differences, and learning outcomes (e.g., Magogwe \& Oliver, 2007; Lee \& Oxford, 2008; Wong \& Nunan, 2011). A range of factors have been found to affect strategy choice, some relating to the learner, and others to the situational and social context of learning. Those investigated variables include learner factors such as age, aptitude, motivation, personality types, learner's personal background etc., and situational and social factors, such as gender, the language being learned, specific learning settings in classroom (Ellis, 2008).

Language learning strategy research began in China in the mid 1980s and has made achievements since 1990s. Chinese researchers have done some studies, and some typical research works on LLSs have appeared (e.g. Wen, 1995; Yang, 1999; Zhang, 2004; Chang, Liu, \& Lee, 2007; Yang, 2007; Wu, 2008; Yu \& Wang, 2009; Zhou, 2010). However, there are still some problems on strategy research in China nowadays. With regard to research subjects, English-majors pre-service teachers are seldom investigated. In terms of research variables, some variables are seldom examined as well, such as personality types. The relatively more researched personality aspect in language studies has been the extroversion-introversion dimension (Dörnyei, 2005). Although Li and Qin (2006) has such claim that judging and perceiving scale has more significant influence on strategy choice 
than extroversion-introversion scale, there are few studies on effects of judging-perceiving scale on strategy use in China. In addition, although gender has been shown to have a strong effect on learners' use of different types of strategies (Rahimi, Riazi, \& Saif, 2011), the results have not come to the agreement either, with mixed results of the effects of gender on LLSs. With regard to research instruments, most researchers just adopt Oxford's (1990) SILL Version 7.0, following the six categories by Oxford (1990), which is not updated and imperative to be adapted to suit the target group of learners in the Chinese context because different cultural and educational contexts will affect the use of LLSs (Rao, 2008).

Because of the research problems mentioned above, the researcher conducted a large-scale survey study on LLS use employed by English-major pre-service teachers in Midwest China in terms of gender and personality types: extroversion-introversion scale and judging-perceiving scale, in order to fill in some research gaps in the field of LLS use in China. Therefore, the purpose of the present research is to investigate the use of LLSs employed by English-major pre-service teachers in Midwest China in relation to their gender and personality types. The investigation was designed to answer the following research questions: (1) What is the frequency of language learning strategy use employed by English-major pre-service teachers in Midwest China in relation to their gender and personality types? (2) Do the choices of language learning strategies vary significantly according to their gender and personality types? If they do, what are the main patterns of variation?

\section{Research Methodology}

\subsection{Key Terms Used in the Present Study}

\subsubsection{Language Learning Strategies}

In the present study, language learning strategies are defined as some general approaches or specific actions/techniques, whether observable or unobservable, which Chinese English-major pre-service teachers generate and make use of to enhance their English language learning directly or indirectly.

\subsubsection{English-Major Pre-Service Teachers}

English-major pre-service teachers refer to students majoring in English in normal universities in China, whose career orientation will be primary or middle school English teachers after graduation. Students will be provided a four-year teacher-training program in normal universities.

\subsubsection{Personality Types}

Personality types refer to the psychological classification of different types of individuals. According to Myers and Myers (1980), personality types include 2 kinds of mental processes: sensing-intuition and thinking-feeling, and 2 kinds of mental orientations: extroversion-introversion and judging-perceiving. The mental orientation scales are the purposively investigated scales in the present study.

According to Ehrman (1996), extroversion-introversion scale refers to where people prefer to focus their attention and get their energy from. Extroverts prefer to focus their attention and get their energy from the outer world of people and activity, while introverts prefer to do this from their inner world of ideas and experiences. Judging-perceiving scale refers to how people prefer to deal with the outer world and take action. Judgers favor a planned and orderly way, seeking closure and finality. Perceivers like flexibility and spontaneity and therefore like to keep their options open. They often resist efforts of others to impose order on their lives.

\subsection{Participants}

The participants for the present study were junior English-major pre-service teachers in Midwest China. As it is a large-scale survey study and there are only a few normal universities which train pre-service teachers in Midwest China, the researcher decided to use the cluster sampling and purposive sampling methods to select the participants. The population was divided into three clusters: Hunan Province, Guizhou Province and Shanxi Province. The researcher first selected two normal universities from each cluster. The participants were then purposively chosen from each of the normal universities based on convenience and availability. At last, 836 subjects from six normal universities were selected, 285 from Hunan Province, 276 from Guizhou Province and 275 from Shanxi Province. The detailed information about the 836 subjects in terms of the chosen variables is in Table 1 as follows. 
Table 1. Number of research participants in terms of gender and personality types

\begin{tabular}{lllll}
\hline Variables & \multicolumn{3}{l}{ Number of Participants } & \\
\hline Gender & & Male (78) & Female (758) & Total (836) \\
\hline Personality & Extroversion-Introversion & Extroversion (496) & Introversion (340) & Total (836) \\
Types & Judging-Perceiving & Judging (655) & Perceiving (181) & Total (836) \\
\hline
\end{tabular}

\subsection{Instruments}

The modified Language Learning Strategy Questionnaire (SILL) and adopted Myers-Briggs Type IndicatorForm M (MBTI-M) were used to collect the data for the present investigation.

\subsubsection{Language Learning Strategy Questionnaire}

The language learning strategy questionnaire used in the present study was combined and modified according to the Strategy Inventory for Language Learning (SILL) Version 7.0 by Oxford (1990), adapted SILL by Yin (2008), and adapted SILL by Rao (2008), following the four categories by Oxford (2011). The strategy items were firstly translated from English into Chinese by the researcher in order to avoid respondents' misunderstanding or unanswering, and then were double checked by two Chinese experts in the field of English Teaching. A 5-point rating scale modifying Oxford's (1990) was used to value the frequency of the strategy use by the participants, which was valued as 1, 2, 3, 4 and 5, representing 'Never or almost never', Usually not, 'Sometimes', 'Usually' and 'Always or Almost always' respectively. The initial questionnaire was piloted with 90 participants in two intact classes, who were excluded in the main study. Among them 6 students were selected for an interview. After the pilot study, strategy items were made some changes based on the feedback of the participants. In the end, the final version was made up of 48 items, including 13 matastrategies (MET), 18 items of cognitive strategies (COG), 7 items of affective strategies (AFF), and 10 items of socio-cultural interactive strategies (SCI). The estimated reliability $(\alpha)$ of the questionnaire in the main study was .92 , which was much higher than the acceptable reliability coefficient of .70, which is the rule of thumb for research purpose (Fraenkel \& Wallen, 2000).

\subsubsection{Personality Type Inventory}

The Myers-Briggs Type Indicator (MBTI) was utilized to identify the participants' personality types. According to Dörnyei (2005), MBTI is the most widely employed personality test in the world, because its validity, reliability, easy scoring, and understanding have been proven by many studies (Thompson and Bing-You, 1998). For the present study, MBTI Form M (MBTI-M) was selected, since it is the most reliable form compared to other forms (Myers et al., 1998), which was translated into Chinese by Cai, Zhu, and Yang (2001), by translating and checking the validity and reliability. The MBTI categorizes individuals based on preference or type, not the strength or degree of preference nor degree of aptitude (Wadligton, 2008). The greater score in each indicator determines the direction of preference (Cai, 2001). Since the present study only explores effects of two scales of personality types: extroversion-introversion and judging-perceiving, the items for the two scales were picked up from the whole items. The piloting of the MBTI-M was conducted to the same participants at the same time with the modified SILL.

\subsection{Data Collection}

The data collection process lasted two months from May to June in 2013. For collecting the data, the researchers went to the six universities in the three provinces in Midwest China in person and administered the questionnaires by themselves to ensure the desirable number of quality responses.

\subsection{Data Analysis}

The data obtained from the questionnaires was input into the computer, and then the SPSS program was conducted to analyze the data. The statistical methods used in the present study included Analysis of Variance (ANOVA) to examine the variations of the students' strategy use at the overall and category levels, and Chi-square test to examine the variations of the LLS use at the individual strategy level.

\section{Findings}

The following are the findings of the present study. The variations in the frequency of pre-service teachers' strategy use in terms of their gender and personality types: extroversion-introversion scale and judging-perceiving scale are presented at the three different levels, i.e. overall, category and individual. 


\subsection{Variations in Frequency of Pre-Service Teachers' Overall LLS Use}

Table 2. Summary of variation in pre-service teachers' overall LLS use

\begin{tabular}{|c|c|c|c|c|c|c|}
\hline Variables & & & Mean & S.D. & Sig. Level & Variation Pattern \\
\hline \multirow{2}{*}{ Gender } & & Male & 2.89 & .54 & \multirow{2}{*}{$\mathrm{P}<.05$} & \multirow{2}{*}{ Female $>$ Male } \\
\hline & & Female & 3.03 & .46 & & \\
\hline \multirow{4}{*}{$\begin{array}{l}\text { Personality } \\
\text { Types }\end{array}$} & Extroversion & Extroversion & 3.09 & .47 & \multirow{2}{*}{$\mathrm{P}<.001$} & \multirow{2}{*}{ Extroversion $>$ Introversion } \\
\hline & $\&$ Introversion & Introversion & 2.92 & .45 & & \\
\hline & \multirow{2}{*}{$\begin{array}{l}\text { Judging } \\
\text { Perceiving }\end{array}$} & Judging & 3.05 & .46 & \multirow{2}{*}{$\mathrm{P}<.01$} & \multirow{2}{*}{ Judging $>$ Perceiving } \\
\hline & & Perceiving & 2.93 & .48 & & \\
\hline
\end{tabular}

As can be seen in Table 2 above, the results from the ANOVA reveal that the frequency of pre-service teachers' overall LLS use varies significantly according to gender and personality types. In terms of their gender, females reported employing strategies significantly more frequently than did the males, with the mean frequency scores of 3.03 and 2.89 respectively. In terms of personality types, extroverts reported employing strategies significantly more frequently than did the introverts, with the mean scores of 3.09 and 2.92, and judgers reported employing strategies significantly more frequently than did the perceivers, with the mean scores of 3.05 and 2.93 separately.

\subsection{Variations in Frequency of Pre-Service Teachers' LLS Use under the Four Categories}

As LLSs for the present study have been classified into the four main categories, i.e. metastrategies (MET), cognitive strategies (COG), affective strategies (AFF), and sociocultural-interactive strategies (SCI). The ANOVA results of Tables 3 to 5 present the significant variations in frequency of pre-service teachers' LLS use in the four categories according to gender and personality types.

3.2.1 Variation According to Pre-Service Teachers' Gender

Table 3. Variation in LLS use in categories according to gender

\begin{tabular}{|c|c|c|c|c|c|c|}
\hline \multirow{2}{*}{$\begin{array}{l}\text { Strategy } \\
\text { Categories }\end{array}$} & \multicolumn{2}{|c|}{ Female $(n=758)$} & \multicolumn{2}{|c|}{ Male $(\mathrm{n}=78)$} & \multirow{2}{*}{ Sig. Level } & \multirow{2}{*}{ Variation Pattern } \\
\hline & Mean & S.D. & Mean & S.D. & & \\
\hline MET Category & 3.07 & .57 & 2.97 & .65 & N.S & - \\
\hline COG Category & 3.01 & .45 & 2.82 & .55 & $\mathrm{P}<.01$ & Female $>$ Male \\
\hline AFF Category & 3.29 & .60 & 3.11 & .80 & $\mathrm{P}<.05$ & Female $>$ Male \\
\hline SCI Category & 2.85 & .59 & 2.77 & .59 & N.S. & - \\
\hline
\end{tabular}

As seen in Table 3 above, significant differences were found in the use of LLSs in the COG and AFF categories by gender. However, no significant variation was found in strategy use in the MET and SCI categories.

3.2.2 Variation According to Pre-Service Teachers' Personality Types

Table 4. Variation in LLS use in categories by extroversion-introversion scale

\begin{tabular}{lllllll}
\hline $\begin{array}{l}\text { Strategy } \\
\text { Categories }\end{array}$ & \multicolumn{2}{l}{$\begin{array}{l}\text { Extroversion } \\
(\mathrm{n}=496)\end{array}$} & \multicolumn{2}{l}{$\begin{array}{l}\text { Introversion } \\
(\mathrm{n}=340)\end{array}$} & Sig. Level & Variation Pattern \\
\cline { 2 - 5 } & Mean & S.D. & Mean & S.D. & & \\
\hline MET Category & 3.13 & .58 & 2.96 & .56 & $\mathrm{P}<.001$ & Extroversion $>$ Introversion \\
COG Category & 3.05 & .47 & 2.91 & .44 & $\mathrm{P}<.001$ & Extroversion $>$ Introversion \\
AFF Category & 3.33 & .59 & 3.20 & .67 & $\mathrm{P}<.01$ & Extroversion $>$ Introversion \\
SCI Category & 2.95 & .59 & 2.68 & .55 & $\mathrm{P}<.001$ & Extroversion $>$ Introversion \\
\hline
\end{tabular}


As shown in Table 5 above, based on the ANOVA results, there exist significant differences in all the four categories by extroversion-introversion scale, with extroverts reporting employing strategies significantly more frequently than introverts.

Table 5. Variation in LLS use in categories by judging-perceiving scale

\begin{tabular}{|c|c|c|c|c|c|c|}
\hline \multirow{2}{*}{ Strategy Categories } & \multicolumn{2}{|c|}{ Judging $(n=655)$} & \multicolumn{2}{|c|}{ Perceiving $(n=181)$} & \multirow{2}{*}{ Sig. Level } & \multirow{2}{*}{ Variation Pattern } \\
\hline & Mean & S.D. & Mean & S.D. & & \\
\hline MET Category & 3.10 & .57 & 2.94 & .58 & $\mathrm{P}<.01$ & Judging $>$ Perceiving \\
\hline COG Category & 3.01 & .47 & 2.93 & .45 & $\mathrm{P}<.05$ & Judging $>$ Perceiving \\
\hline AFF Category & 3.30 & .61 & 3.20 & .67 & N.S & - \\
\hline SCI Category & 2.87 & .57 & 2.72 & .63 & $\mathrm{P}<.01$ & Judging $>$ Perceiving \\
\hline
\end{tabular}

In respect of pre-service teachers' judging-perceiving scale, the results in Table 4 above show that significant differences were found in LLS use in the MET, COG and SCI categories, with judgers reporting employing strategies significantly more frequently than perceivers. However, no significant variation was found in strategy use in the AFF category.

\subsection{Variations in Frequency of Pre-Service Teachers' Individual LLS Use}

This section is to present the results of the Chi-square tests to determine the patterns of the significant variations in students' reported strategy use at the individual strategy level in terms of gender and personality types: extroversion-introversion scale and judging-perceiving scale. The percentage of students' high strategy use (4 and 5 in the LLS questionnaire), and the observed Chi-square value $\left(\chi^{2}\right)$ which shows the strength of variation in each individual strategy use were identified. The individual strategies are presented in descending order of percentage of students' reporting high use in the LLS questionnaire.

\subsubsection{Variation in Individual LLS Use According to Pre-Service Teachers' Gender}

Table 6. Variation in individual LLS use according to gender

\begin{tabular}{|c|c|c|c|}
\hline \multirow{2}{*}{$\begin{array}{l}\text { Individual LLSs } \\
\text { Used more by Female }>\text { Male (11 LLSs) }\end{array}$} & \multicolumn{2}{|c|}{$\%$ of high use (4 and 5 ) } & \multirow{2}{*}{ Observed $\chi^{2}$} \\
\hline & Female & Male & \\
\hline $\begin{array}{l}\text { COG 20. Using a circumlocution if one can't think of a precise } \\
\text { English word. }\end{array}$ & 69.1 & 57.7 & $\chi^{2}=8.93 *$ \\
\hline $\begin{array}{l}\text { AFF } 30 . \text { Telling oneself that there is always more to learn when } \\
\text { learning English. }\end{array}$ & 64.1 & 52.6 & $\chi^{2}=16.57 * * *$ \\
\hline $\begin{array}{l}\text { MET 42. Systematically reviewing vocabulary, texts and notes } \\
\text { before exams. }\end{array}$ & 63.3 & 48.7 & $\chi^{2}=19.84 * * *$ \\
\hline MET 9. Watching English-speaking movies or TV programs. & 59.5 & 52.6 & $\chi^{2}=16.39 * *$ \\
\hline $\begin{array}{l}\text { SCI 33. Asking the interlocutor to slow down or say it again if } \\
\text { one doesn't understand. }\end{array}$ & 52.2 & 41.0 & $\chi^{2}=19.27 * * *$ \\
\hline MET 47. Doing a lot of exam-oriented exercises before exams. & 51.6 & 37.2 & $\chi^{2}=9.41 * *$ \\
\hline MET 22. Trying to find out how to learn English well. & 50.8 & 42.3 & $\chi^{2}=7.79 *$ \\
\hline COG 15. Guessing the meaning of the unfamiliar English words. & 49.3 & 30.8 & $\chi^{2}=12.11 * *$ \\
\hline COG 18. Reading English without looking up every new word. & 47.0 & 35.9 & $\chi^{2}=7.59 *$ \\
\hline $\begin{array}{l}\text { COG } 41 \text {. Trying to understand the complex English sentences by } \\
\text { analyzing their grammatical structures. }\end{array}$ & 46.3 & 29.5 & $\chi^{2}=11.81 * *$ \\
\hline COG 5. Saying or writing new English words several times. & 45.3 & 25.6 & $\chi^{2}=18.33 * *$ \\
\hline Used more by Male $>$ Female ( 5 LLSs) & Male & Female & \\
\hline $\begin{array}{l}\text { AFF 27. Trying to relax whenever feeling afraid of using } \\
\text { English. }\end{array}$ & 41.0 & 40.8 & $\chi^{2}=11.58 * *$ \\
\hline
\end{tabular}




\begin{tabular}{llll}
\hline MET 25. Having clear goals for improving one's English skills. & 39.7 & 28.9 & $\chi^{2}=7.61^{*}$ \\
COG 14. Trying not to translate verbatim. & 38.5 & 36.5 & $\chi^{2}=16.32^{* * *}$ \\
$\begin{array}{l}\text { COG 1. Thinking of relationships between what one already } \\
\text { knows and new things one learns in English. }\end{array}$ & 28.2 & 25.9 & $\chi^{2}=26.15^{* *}$ \\
$\begin{array}{l}\text { COG 2. Using new English words in a sentence so that one can } \\
\text { remember them. }\end{array}$ & 21.8 & 14.6 & $\chi^{2}=8.46^{*}$ \\
\hline
\end{tabular}

Notes: $* \mathrm{P}<.05, * * \mathrm{P}<.01, * * * \mathrm{P}<.001$.

Table 6 above demonstrates significant variations in use of individual LLSs in terms of gender. The results of the Chi-square tests reveal two different variation patterns according to this variable.

The first variation pattern, 'female>male', indicates that a significantly greater percentage of the female students than their male counterparts reported high use of 11 LLSs, among which 7 strategies were reported high frequency of use by more than 50 percent of the female participants. Examples are, 'Using a circumlocution if one can't think of a precise English word' (COG 20), 'Telling oneself that there is always more to learn when learning English' (AFF 30), and 'Systematically reviewing vocabulary, texts and notes before exams' (MET 42).

The second variation pattern is 'male>female', indicating a significantly greater percentage of the male students than their female counterparts, with high use of 5 LLSs. Examples are, 'Trying to relax whenever feeling afraid of using English' (AFF 27), 'Having clear goals for improving one's English skills' (MET 25), and 'Trying not to translate verbatim' (COG 14). No LLS was found to have a high reported frequency of use by more than 50 percent of the male participants.

\subsubsection{Variation in Individual LLS Use According to Pre-Service Teachers' Personality Types}

In this section, the results from the Chi-square tests reveal that 27 individual strategies varied significantly in terms of extroversion-introversion scale, and 13 individual strategies varied significantly in relation to judgingperceiving scale.

Table 7. Variation in individual LLS use according to extroversion-introversion scale

\begin{tabular}{|c|c|c|c|}
\hline Individual LLSs & $\%$ of high use & 4 and 5) & Obcrud ${ }^{2}$ \\
\hline Used more by Extroversion > Introversion (27 LLSs) & Extroversion & Introversion & Ooserved $x$ \\
\hline $\begin{array}{l}\text { SCI } 33 \text { Asking the interlocutor to slow down or say it again if } \\
\text { one doesn't understand }\end{array}$ & 55.6 & 44.7 & $\chi^{2}=10.15^{* *}$ \\
\hline $\begin{array}{l}\text { MET } 12 \text {. Listening to English radio programs, news or songs } \\
\text { on the Internet, by an MP } 3 / 4 \text { or a mobile phone }\end{array}$ & 53.8 & 42.9 & $\chi^{2}=11.38 * *$ \\
\hline $\begin{array}{l}\text { COG } 15 \text { Guessing the meaning of the unfamiliar English } \\
\text { words }\end{array}$ & 51.2 & 42.4 & $\chi^{2}=7.37^{*}$ \\
\hline $\begin{array}{l}\text { AFF } 28 \text { Encouraging oneself to speak English even when one } \\
\text { is afraid of making mistakes }\end{array}$ & 51.2 & 34.1 & $\chi^{2}=24.76 * * *$ \\
\hline $\begin{array}{l}\text { SCI } 37 \text { Trying to learn about the culture of English-speaking } \\
\text { countries }\end{array}$ & 45.2 & 38.2 & $\chi^{2}=8.51^{*}$ \\
\hline $\begin{array}{l}\text { AFF } 29 \text { Giving oneself a reward or treat when one does well } \\
\text { in English }\end{array}$ & 42.7 & 34.1 & $\chi^{2}=28.76^{*} * *$ \\
\hline SCI 43 Participating in English classroom activities & 41.7 & 21.5 & $\chi^{2}=48.88 * * *$ \\
\hline $\begin{array}{l}\text { COG } 13 \text { Getting the meaning of an English word by dividing } \\
\text { it into parts that one understands, such as roots, prefixes, and } \\
\text { suffixes }\end{array}$ & 37.1 & 26.5 & $\chi^{2}=10.37 * *$ \\
\hline $\begin{array}{l}\text { MET } 25 \text { Having clear goals for improving one's English } \\
\text { skills }\end{array}$ & 33.5 & 24.7 & $\mathrm{x} 2=12.59 * *$ \\
\hline $\begin{array}{l}\text { AFF } 32 \text { Talking to someone else about how one feels when } \\
\text { learning English }\end{array}$ & 32.9 & 25.0 & $\chi^{2}=13.11 * *$ \\
\hline SCI 8 Trying to talk like native speakers & 31.3 & 26.8 & $\chi^{2}=17.29 * * *$ \\
\hline
\end{tabular}




\begin{tabular}{|c|c|c|c|}
\hline MET 38 Practicing English reading on the Internet & 30.8 & 24.7 & $\chi^{2}=10.64 * *$ \\
\hline $\begin{array}{l}\text { MET } 24 \text { Looking for opportunities/ chances to read as much } \\
\text { as possible in English }\end{array}$ & 30.6 & 22.1 & $\chi^{2}=9.98 * *$ \\
\hline SCI 36 Asking for help from one's English teacher or friends & 30.0 & 22.9 & $\chi^{2}=9.90 * *$ \\
\hline $\begin{array}{l}\text { SCI } 16 \text { Using gestures to convey one's meaning during a } \\
\text { conversation in English }\end{array}$ & 29.4 & 21.2 & $\chi^{2}=12.34 * *$ \\
\hline $\begin{array}{l}\text { COG } 1 \text { Thinking of relationships between what one already } \\
\text { knows and new things one learns in English }\end{array}$ & 29.0 & 21.8 & $\chi^{2}=6.04 *$ \\
\hline $\begin{array}{l}\text { SCI } 34 \text { Asking one's English teacher or fluent speakers of } \\
\text { English to correct when one is talking }\end{array}$ & 28.0 & 19.4 & $\chi^{2}=9.92 * *$ \\
\hline $\begin{array}{l}\text { MET } 23 \text { Planning one's schedule so one will have enough } \\
\text { time to learn English }\end{array}$ & 25.8 & 15.0 & $\chi^{2}=16.07 * * *$ \\
\hline MET 45 Improving one's English from different websites. & 23.6 & 16.8 & $\chi^{2}=13.82 * *$ \\
\hline COG 6 Reviewing English lessons often & 23.2 & 14.7 & $\chi^{2}=11.35 * *$ \\
\hline $\begin{array}{l}\text { SCI } 34 \text { Asking one's English teacher or fluent speakers of } \\
\text { English to correct when one is talking }\end{array}$ & 28.0 & 19.4 & $\chi^{2}=9.92 * *$ \\
\hline $\begin{array}{l}\text { MET } 23 \text { Planning one's schedule so one will have enough } \\
\text { time to learn English }\end{array}$ & 25.8 & 15.0 & $\chi^{2}=16.07 * * *$ \\
\hline MET 45 Improving one’s English from different websites. & 23.6 & 16.8 & $\chi^{2}=13.82 * *$ \\
\hline COG 6 Reviewing English lessons often & 23.2 & 14.7 & $\chi^{2}=11.35^{* *}$ \\
\hline SCI 35 Practicing speaking English with other students & 21.6 & 9.4 & $\chi^{2}=31.13 * * *$ \\
\hline $\begin{array}{l}\text { COG } 2 \text { Using new English words in a sentence so that one } \\
\text { can remember them }\end{array}$ & 17.7 & 11.8 & $\chi^{2}=12.06^{*} *$ \\
\hline SCI 46 Participating in extra-curricular activities & 16.3 & 11.5 & $\chi^{2}=25.12 * * *$ \\
\hline $\begin{array}{l}\text { COG } 17 \text { Making up new words if one does not know the } \\
\text { precise ones in English }\end{array}$ & 14.9 & 9.1 & $\chi^{2}=11.27 * *$ \\
\hline $\begin{array}{l}\text { SCI } 39 \text { Getting in touch with one's friends in English, for } \\
\text { example, writing e-mails or letters }\end{array}$ & 14.9 & 9.1 & $\chi^{2}=9.95 * *$ \\
\hline MET 44 Attending extra classes at a language school & 13.3 & 6.8 & $\chi^{2}=21.42 * * *$ \\
\hline COG 11 Writing diaries or short articles in English & 11.5 & 10.6 & $\chi^{2}=6.15^{*}$ \\
\hline Used more by Introversion > Extroversion (1 LLS) & Introversion & Extroversion & \\
\hline $\begin{array}{l}\text { AFF } 31 \text { Noticing whether one is nervous or not when reading } \\
\text { or using English }\end{array}$ & 43.2 & 37.9 & $\chi^{2}=7.24^{*}$ \\
\hline
\end{tabular}

Note: $* \mathrm{P}<.05, * * \mathrm{P}<.01, * * * \mathrm{P}<.001$.

The Chi-square results in Table 7 above demonstrate that significant variations in use of 28 individual LLSs were found by extroversion-introversion, with two variation patterns.

The first variation pattern is 'extroversion>introversion',indicating that a significantly higher percentage of extroverts reported high use of 27 strategies than introverts, among which 4 strategies were reported high frequency of use by more than 50 percent of the extroverts, which are: 'Asking the interlocutor to slow down or say it again if one doesn't understand' (SCI 33), 'Listening to English radio programs, news or songs on the Internet, by an MP3/4 or a mobile phone' (MET 12), 'Guessing the meaning of the unfamiliar English words' (COG 15), and 'Encouraging oneself to speak English even when one is afraid of making mistakes' (AFF 28).

The second variation pattern is 'introversion>extroversion'. A significantly higher percentage of introverts reported high use of only 1 strategy than extroverts, which is 'Noticing whether one is nervous or not when reading or using English' (AFF 31). 
Table 8. Variation in individual LLS use according to judging-perceiving scale

\begin{tabular}{|c|c|c|c|}
\hline Individual LLSs & $\%$ of high $\mathrm{u}$ & e (4 and 5) & Observed $\chi^{2}$ \\
\hline Used more by Judging > Perceiving (12 LLSs) & Judging & Perceiving & \\
\hline $\begin{array}{l}\text { MET } 12 \text { Listening to English radio programs, news or songs on } \\
\text { the Internet, by an MP } 3 / 4 \text { or a mobile phone }\end{array}$ & 51.3 & 42.5 & $\chi^{2}=6.00^{*}$ \\
\hline $\begin{array}{l}\text { COG } 41 \text { Trying to understand the complex English sentences by } \\
\text { analyzing their grammatical structures }\end{array}$ & 46.7 & 37.6 & $\chi^{2}=8.64^{*}$ \\
\hline $\begin{array}{l}\text { AFF } 28 \text { Encouraging oneself to speak English even when being } \\
\text { afraid of making mistakes }\end{array}$ & 46.6 & 35.9 & $\mathrm{x} 2=6.52^{*}$ \\
\hline $\begin{array}{l}\text { COG } 7 \text { Remembering new English words or phrases by } \\
\text { remembering the context in which they appear }\end{array}$ & 36.5 & 26.5 & $\chi^{2}=6.38^{*}$ \\
\hline SCI 43 Participating in English classroom activities & 35.9 & 24.9 & $\chi^{2}=7.12 *$ \\
\hline MET 26 Thinking about one's progress in learning English & 35.7 & 30.9 & $\mathrm{x} 2=9.94 * *$ \\
\hline MET 25 Having clear goals for improving one's English skills & 32.1 & 22.1 & $\chi^{2}=10.84 * *$ \\
\hline SCI 36 Asking for help from one's English teacher or friends & 27.2 & 27.1 & $\chi^{2}=7.39^{*}$ \\
\hline $\begin{array}{l}\text { SCI } 34 \text { Asking one's English teacher or fluent speakers of English } \\
\text { to correct when one is talking }\end{array}$ & 26.4 & 17.7 & $\chi^{2}=6.81 *$ \\
\hline $\begin{array}{l}\text { MET } 23 \text { Planning one's schedule so one will have enough time to } \\
\text { learn English }\end{array}$ & 23.5 & 13.8 & $\chi^{2}=13.25 * *$ \\
\hline COG 6 Reviewing English lessons often & 22.1 & 11.0 & $\chi^{2}=12.71 * *$ \\
\hline MET 45 Improving one's English from different websites & 21.8 & 17.1 & $\chi^{2}=8.60 *$ \\
\hline Used more by Perceiving > Judging (1 LLS) & Perceiving & Judging & \\
\hline $\begin{array}{l}\text { COG } 17 \text { Making up new words if one does not know the precise } \\
\text { ones in English }\end{array}$ & 14.4 & 12.1 & $\chi^{2}=13.31 * *$ \\
\hline
\end{tabular}

Notes: * $\mathrm{P}<.05, * * \mathrm{P}<.01, * * * \mathrm{P}<.001$.

As shown in Table 4.18 above, the Chi-square results demonstrate that significant variations in use of 13 individual LLSs were found according to judging-perceiving. Two variation patterns were found, i.e. 'judgers $>$ perceivers', and 'perceivers $>$ judgers'.

The first variation pattern is 'judgers>perceivers'. A significantly greater percentage of the judgers reported high use of 12 strategies than the perceivers, among which 1 strategy was reported high frequency of use by more than 50 percent of the extroverts, which is, 'Listening to English radio programs, news or songs on the Internet, by an MP3/4 or a mobile phone' (MET 12).

The second variation pattern is 'perceivers >judgers'. A significantly greater percentage of perceivers reported high use of only 1 strategy than judgers, which is, 'Making up new words if one does not know the precise ones in English' (COG 17), reported high frequency of use by much less than 50 percent of the perceivers.

\section{Discussion}

The present study was intended to explore the use of LLSs by English-major pre-service teachers in Midwest China in relation to gender and personality types. The results mentioned above were discussed as follows:

\subsection{Use of LLSs and Pre-Service Teachers' Gender}

The findings demonstrated that female pre-service teachers show significantly higher frequency of overall strategy use, use of strategies in COG and AFF categories, and use of 11 individual LLSs than their male counterparts. In addition, 5 individual strategies were reported being used significantly more frequently by males than females.

Firstly, the research results indicate that there is a relationship between pre-service teachers' use of LLSs and their gender, which is consistent with the results of many previous studies. Oxford and Nyikos (1989) find that gender had 'a profound effect on strategy choice' in their study of university students learning foreign languages. Intaraprasert (2000) points out that males and females have their own ways of using strategies to learn a foreign or second language, Kyungsim and Leavell (2006) discover statistically significant difference in the use of 
affective strategies between male and female, and Radwan (2011) finds significant difference between male students and female students in using social strategies.

Secondly, the results reveal that female pre-service teachers employ strategies generally significantly more frequently than their male counterparts, which is partly proved by some previous studies. According to Green and Oxford (1995), women use more strategies than men, especially in the use of affective and social strategies. Sheorey's (1999) study on Indian college students studying English reported that female samples use strategies significantly more frequently than male students. Hong-Nam and Leavell (2006) find that females report employing affective and social strategies more frequently than male learners. Ghee, Ismail and Kabilan (2010) determine that female students use more learning strategies than the male students in affective strategies.

Regarding the differences in the pre-service teachers' LLS use in relation to gender in the present study, a few tentative explanations could be hypothesized to interpret the variations. The first possible factor which may explain why female pre-service teachers reported employing LLS use more frequently than their male counterparts in the overall strategy use and use of strategies in the COG and AFF categories is the worldwide belief that females are superior to males in language learning (Rao, 2008), as Oxford, Nyikos and Ehrman (1988) put forward that the language learning folklore that women learn languages better than men. Dai and Lynn (1994) also point out that the high level of cross-cultural consistency in the strategy use by gender lends support to the possibility that females have a greater potential in language learning than males by birth.

The second possible explanation for females' significantly higher frequency use of LLSs is females' need for social approval (Nyikos, 1990). Several distinctive features emerged from the LLSs used significantly frequently by the females. One was related to the female pre-service teachers' desire for good grades according to Kramarae (1981), as expressed by the two strategies: "Systematically reviewing vocabulary, texts and notes before exams" (MET 42) and "Doing a lot of exam-oriented exercises before exams" (MET 47). Another one is concerned with female pre-service teachers' special interest in rule-related practice and rote memory, as in the two strategies "Trying to understand the complex English sentences by analyzing their grammatical structures" (COG 41) and "Saying or writing new English words several times" (COG 5), which could also be related to females' desire for good grades and may reflect a need for social approval (Nyikos, 1990). Also another is related to females' motivation to learn English in order to satisfy their social expectations, as expressed in the two strategies "Telling oneself that there is always more to learn when learning English" (AFF 30) and "Trying to find out how to learn English well" (MET 22). All the above explanations are well suited to the Chinese context where social approval is of utmost importance for females (Rao, 2008).

The third possible explanation for such significant difference is females' sociability. Oxford (1995) points out that both brain hemisphericity and socialization differences between male and female have attributed to the differences in strategy use. Two LLSs "Using a circumlocution if one can't think of a precise English word" (COG 20) and "Asking the interlocutor to slow down or say it again if one doesn't understand" (SCI 33) shows their strong desire for sociability, which is consistent with what Ok (2003, p. 26) mentions, "females are superior to, or at least very different from, males in many social skills with females showing a greater social orientation". A popular belief is that females are better L2 learners than males. If so, it probably resulted from the development of more effective social interaction skills and strategies in female than male students (Hall, 2011).

In another aspect, according to Ghani (2003, p. 33), "males do better than females in the use of some strategies", which is supported by the findings of the present study where male pre-service teachers did report using five strategies significantly than did there female counterparts. The possible explanation for this is males' social position in China. Rao (2008, p. 261) put forward the concept of male-dominated social structure, as "from childhood onwards, a Chinese man is nurtured not to be in front of difficulties. No matter how difficult it would be, a man should never be discouraged and try his best to reach his goal." That is consistent with what Maubach and Morgan (2001) claimed that male pre-service teachers had greater willingness to manage anxiety while interacting in English than female counterparts, thus males are quite self-confident and risk-taking. Therefore, male pre-service teachers could manage to control their anxiety as in strategy "Trying to relax whenever feeling afraid of using English" (AFF 27), could feel so confidant and take risk to learn English in ways of association or creation as in strategies "Trying not to translate verbatim" (COG 14), "Thinking of relationships between what one already knows and new things one learns in English" (COG 1), and "Using new English words in a sentence so that one can remember them" (COG 2), and could have the ability of have their clear goals in English learing as in strategy "Having clear goals for improving one's English skills" (MET 25).

In sum, the four hypothesized explanations: the worldwide belief that females are superior to males in language learning, females' need for social approval, females' sociability, and males' social position are possibly 
attributed to the significant variations in pre-service teachers' LLSs use by gender.

\subsection{Use of LLSs and Pre-Service Teachers' Personality Types}

The findings of the present investigation indicate that significant variations in pre-service teachers' choices of strategy use exist in respect of personality types: extroversion-introversion scale and judging-perceiving scale. This finding is consistent with some previous studies (e.g. Ehrman \& Oxford, 1990; Ellis, 1994; Oxford \& Ehrman, 1995; Wakamoto, 2000; Liyange, 2004; Li \& Qin, 2006; Sharp, 2008). However, it does not fit in with some other studies, which have failed to find relationships between personality and strategy use (e.g. Carrell et al., 1996; Conti \& Kolody, 1999; Sharp, 2008; Conti \& McNeil, 2011). The contradiction of the results may be due to various methodological deficiencies or because the effects of personality types may be situation-dependent or mediated by other variables (Dörnyei, 2005).

When taking the two scales into consideration, we found that significant variations exist in students' strategy use in all the four MET, COG, AFF and SCI categories and in the use of 28 out of 48 individual strategies in terms of extroversion-introversion scale, while there is no significant variation in the AFF category and only 13 out of 48 individual strategies according to judging-perceiving scale. We can come to such a conclusion that extroversion-introversion scale has more influence on LLS choice than judging- perceiving scale. This is not consistent with what Li and Qin (2006) claimed that judging-perceiving has more influence on strategy choice than extroversion-introversion. The inconsistency of the findings may be due to the different participants and research instruments in the two studies.

\subsubsection{Use of LLSs in Association with Extroversion-Introversion Scale}

Extroversion has been one of the most discussed personality factors in language learning and the findings of previous studies on extroversion appear to be varied (Kang, 2012). The extroversion- introversion scale references a tendency to prefer stimulation, company of others, and engagement with the external world (Costa \& McCrae, 1992). The majority of findings from previous studies on the relationships between extroversion-introversion and LLS use have reported that extroverted students preferred to use social strategies (Ehrman \& Oxford, 1989, 1990; Li \& Qin, 2006; Sharp, 2008), functional practice and social-affective strategies (Wakamoto, 2000; Liyanage, 2004), and affective and visualization strategies (Ehrman \& Oxford, 1989). In comparison, introverted students preferred to use metacognitive strategies while avoiding using social strategies (Ehrman \& Oxford, 1990; Sharp, 2008) and strategies for searching for and communicating meaning (Ehrman \& Oxford, 1989).

The current study found that there exist significant variations in their reported frequency of in all the four categories: MET, COG, AFF and SCI in terms of extroversion-introversion. The main variation pattern is that extroverts reported employing strategies significantly more frequently than did the introverts, with 27 out of 28 individual strategies reporting this, among which there are 7 out of 13 MET, 7 out of 18 COG, 3 out of 7 AFF, and 10 out of $10 \mathrm{SCI}$. The second variation pattern is that introverts reported employing strategies significantly more frequently than did the extroverts, only 1 strategy reported this.

For the main variation pattern, the most significant frequent strategy use by extroverts is SCI (sociocultural-interactive strategies). The possible reason to explain this is extroverts' sociability, an essential feature of extroversion (Ellis, 2008). According to Eysenck and Chan (1982, p. 154), "extroverts are sociable, like parties, have many friends and need excitement; they are sensation-seeker and risk-takers, like practical jokes and are lively and active." In accordance with Wakamoto (2000), extroverts prefer social strategies, like cooperation with others or asking for clarification, and functional practice strategies like seeking practice opportunities outside class. Sociability, the essential feature of extroversion, just matches with the contents of sociocultural-interactive strategies, which are for contexts, communication, and culture, with the functions of interacting to learn and communicate, overcoming knowledge gaps in communicating, and match with the functions of dealing with sociocultural contexts and identities, etc (Oxford, 2011). The examples of SCI are: "Asking the interlocutor to slow down or say it again if one doesn't understand" (SCI 33), "Participating in English classroom activities" (SCI 43), and "Asking for help from one's English teacher or friends" (SCI 36).

Another significant frequent strategy use by extroverts is MET (metastrategies). This is in accordance with Li and Zhang's (2009) and Kang's (2012) studies that extroverts showed more frequent use of metacognitive strategies, while it is contrary to what Ehrman and Oxford (1990) and Sharp (2008) found that introverted students preferred to use metacognitive strategies. The possible explanation for the contradiction of the results could be attributed to learners' learning environments (Kang, 2012), or situation-dependence of the effects on strategy choice of personality types (Dörnyei, 2005). 
For the present study, extroverts use metastrategies significantly more frequently than introverts as follows: "Practicing English reading on the Internet" (MET 38), "Improving one's English from different websites" (MET 45), "Listening to English radio programs, news or songs on the Internet, by an MP3/4 or a mobile phone" (MET 12), which are for obtaining and using resources; "Having clear goals for improving one's English skills" (MET 25), and "Planning one's schedule so one will have enough time to learn English" (MET 23), which are for planning or organizing; "Looking for opportunities/ chances to read as much as possible in English" (MET 24), which is for monitoring; "Attending extra classes at a language school" (MET 44), which is for implementing plans. The possible explanation may be because extroverted pre-service teachers prefer to use MET to deal with the environment rather than with themselves (Ehrman \& Oxford, 1990), or to cope with the educational contexts (Sharp, 2008) in which extroverts prefer to use MET to succeed in school exams and university exams, as Li and Zhang (2009) stated, metacogitive strategies require learners to interact with outer world, since metacogitive strategies are concerned with controlling and regulating strategy use and learning processes, and as Oxford (2011) considers metastrategies as strategies that provide general management/ control of cognitive strategies, including metacognitive, meta-affective and metasocial strategies, with the functions of paying attention, planning, obtaining and using resources, organizing, implementing plans, orchestrating strategy use, monitoring, evaluating, etc.

The second variation pattern shows that introverts reported employing strategies significantly more frequently than did the extroverts. The only strategy reported this is "Noticing whether one is nervous or not when reading or using English" (AFF 31). The possible explanation for this could be introverted learners' natural preference that they prefer more to learning alone best, avoiding social contact and surprise (Wakamoto, 2000), so that they are more easily become nervous and pay attention to the feelings of nervousness.

\subsubsection{Use of LLSs in Association with Judging-Perceiving Scale}

Ehrman and Oxford's (1989) study shows that for the judging-perceiving scale, judgers report using general strategies significantly more frequently than perceivers, but do not use independent strategies and self-management strategies significantly more often, while perceivers show an advantage over judgers in the use of strategies for searching for and communicating meaning. According to Li and Qin (2006), judging is found to significantly influence seven strategies, turning out to be the most influential personality type affecting the use of learning strategies. Judging learners indicate clear preference for the metacognitive strategy.

In this present investigation, the judgers reported employing strategies significantly frequently than perceivers in all the four categories except AFF category, with 5 metastrategies, 3 cognitive strategies, 3 socio-cultural interactive strategies, and 1 affective strategy. The main variation pattern is that judgers reported employing strategies significantly more frequently than did perceivers, with 12 out of 28 individual strategies reported this, among which there are 5 out of 13 MET, 3 out of 18 COG, 3 out of 10 SCI, and 1 out of 7 AFF. The second variation pattern is that introverts reported employing strategies more frequently than judgers, concerned with only 1 strategy.

The main findings of the main variation pattern are consistent with what Ehrman and Oxford (1989) and Li and Qin (2006) claim that there is a significant variation in learners' choices of LLSs in relation to judging-perceiving scale. The most frequently reported used category is metastrategy. The examples are: 'Listening to English radio programs, news or songs on the Internet, by an MP3/4 or a mobile phone' (MET 12) with the aim of obtaining and using resources, 'Thinking about one's progress in learning English' (MET 26) for evaluating, 'Having clear goals for improving one's English skills' (MET 25) with the aim of planning. The result is consistent with what $\mathrm{Li}$ and Qin (2006) claimed that judging learners indicate clear preference for the metacognitive strategy. The possible explanation of higher frequency of strategy use by judgers may be due to what Ellis (2008) called essential feature. According to Ehrman (1996), judging learners favor a planned and orderly way, seeking closure and finality. According to Myers and McCaulley (1985), judgers' natural preferences for structure, organization, system and control may well be expressed in their needs of the metacognitive strategies.

The second variation pattern is that introverts reported employing strategies more frequently than judgers, concerned with only 1 trategy: 'Making up new words if one does not know the precise ones in English' (COG 17). The possible explanation could also be due to what Ellis (2008) called essential feature. According to Ehrman (1996), perveiving learners like flexibility and spontaneity and therefore like to keep their options open. Therefore, they could be flexible to make up new words when the do not know the procise ones.

To summarize, the findings of the present study show that there exist effects on pre-service teachers' LLS choices by personality types: extroversion-introversion scale and judging-perceiving scale, which is consistent 
with most previous studies, while contrary to some previous ones. The contradiction of the results is possibly because there are different research methods in different studies, or the effects of personality types may be situation-dependent or mediated by other variables. The main variation patterns for personatlity types are that extroverts employed strategies significantly more frequently than entroverts, and judgers employed strategies significantly more frequently than perveivers, which may be due to their essential feature or natural inclination. Nevertheless, there has been no definitely certain evidence for what really caused these significant differences. Therefore, investigation of these aspects is still necessary.

\section{Conclusion}

This study investigated the use of LLSs employed by English-major pre-service teachers in Midwest China in relation to their gender and personality types. The results demonstrated that females show significantly higher frequency of overall strategy use, use of strategies in COG and AFF categories, and use of 11 individual LLSs than males, while only 5 individual strategies were reported being used significantly more frequently by males than females. In addition, there exist significant variations in students' choices of strategy use in respect of personality types. There are significant variations in students' strategy use in all the four MET, COG, AFF and SCI categories by extroversion-introversion scale, while only in MET, COG and SCI categories by judging-perceiving scale. The results also show that significant variations exist in the use of 28 out of 48 individual strategies by extroversion- introversion, while only exist in 13 out of 48 individual strategies by judging-perceiving. We can come to such a conclusion that extroversion-introversion scale has more influence on LLS choice than judging-perceiving scale. The results give some implications as follows: Firstly, it is better for English teachers to encourage these pre-service teachers to employ a wide range of LLSs for the purpose of learning English better; Secondly, male students need more help in developing their language learning strategies; Thirdly, it is highly recommended that English teachers should consider individual language learners' different personality types, give different instructions, set differently appropriate tasks, or give different checking criteria of tasks to students with different personality types.

\section{References}

Carrell, P., Prince, M., \& Astika, G. (1996). Personality types and language learning in an EFL context. Language Learning, 46, 75-99. http://dx.doi.org/10.1111/j.1467-1770.1996.tb00641.x

Chamot, A. U., \& O'Malley, J. M. (1987). A cognitive academic language learning approach: A bridge to the mainstream. TESOL Quarterly, 21, 227-249. http://dx.doi.org/10.2307/3586733

Chang, C. Y., Liu, S. C., \& Lee, Y. N. (2007). A study of language learning strategies used by college EFL learners in Taiwan. Mingdao Journal of General Education, 3, 235-261.

Conti, G. J., \& Kolody, R. C. (1999a). The relationship of learning strategy preference and personality type. Proceedings of the Annual Adult Education Research Conference. DeKalb, IL: Northern Illinois University. Retrieved from http://www.adulterc.org/Proceedings/1999/99conti.htm

Conti, G. J., \& McNeil, R. C. (2011). Learning strategy preference and personality type: Are they related? Journal of Adult Education, 40(2), 1-8.

Costa, P. T., Jr., \& McCrae, R. R. (1992). NEO PI-R professional manual. Odessa, FL: Psychological Assessment Resources.

Dai, X. Y., \& Lynn, R. (1994). Gender differences in intelligence among Chinese children. Journal of Social Psychology, 134(1), 123-125. http://dx.doi.org/10.1080/00224545.1994.9710892

Dörnyei, Z. (2005). The psychology of the language learner: Individual differences in second language acquisition. Mahwah, NJ: Lawrence Erlbaum.

Ehrman, M. (1990). The role of personality type in adult language learning: An ongoing investigation. In T. Parry, \& C. Stansfield (Eds.), Language Aptitude Reconsidered. Englewood Cliffs, N.J.: Prentice Hall.

Ehrman, M., \& Oxford, R. (1989). Effects of sex differences, career choice, and psychological type on adult language learning strategies. The Modern Language Journal, 73, 1-13. http://dx.doi.org/10.1111/j.1540-4781.1989.tb05302.x

Ehrman, M., \& Oxford, R. (1990). Adult language learning styles and strategies in an intensive training setting. Modern Language Journal, 74, 311-317. http://dx.doi.org/10.1111/j.1540-4781.1990.tb01069.x

El-Dib, M. A. B. (2004). Language learning strategies in Kuwait: Links to gender, language level, and culture in a hybrid context. Foreign Language Annuals, 37(1), 85-95. http://dx.doi.org/10.1111/j.1944-9720.2004. 
tb02176.x

Ellis, R. (1994). The study of second language acquisition. Oxford University Press. Oxford.

Ellis, R. (2008). The study of second language acquisition. Oxford University Press, Oxford.

Eysenck, S. B. G., \& Chan, J. (1982). A comparative study of personality in adults and children: Hong Kong vs England. Personality and Individual Differences, 3, 153-160. http://dx.doi.org/10.1016/0191-8869 (82)90029-0

Fraenkel, J. R., \& Wallen, N. E. (2000). How to design and evaluate research in education. New York, NY: Mc Grawhill Companies Inc.

Ghani, M. (2003). Language learning strategies employed by L2 learners. Journal of Research, 4, 31-36.

Ghee, T. T., Ismail, H. N., \& Kabilan, M. K. (2010). Language learning strategies used by MFL students based on genders and achievement groups. US-China Foreign Language, 8(1), 50-58.

Green, J. M., \& Oxford, R. (1995). A close look at learning strategies, L2 proficiency, and gender. TESOL Quarterly, 29(2), 261-297. http://dx.doi.org/10.2307/3587625

Hall, G. (2011). Exploring English language teaching language in action. NewYork: Routledge Hall.

Hong-Nam, K., \& Leavell, A. G. (2006). Language learning strategy use of ESL students in an intensive English learning context. System, 34, 399-415. http://dx.doi.org/10.1016/j.system.2006.02.002

Intaraprasert, C. (2000). Language learning strategies employed by engineering students learning English at the tertiary level in Thailand (Unpublished doctoral dissertation). University of Leeds, the United Kingdom.

Kang, S. Y. (2012). Individual Differences in Language Acquisition: Personality Traits and Language Learning Strategies of Korean University Students Studying English as a Foreign Language (Unpublished doctoral dissertation). Indiana State University, Indiana.

Kavasoglu, M. (2009). Learning strategy use of pre-service teachers of English language at Mersin University. Procedia Social and Behavioral Sciences, 1, 993-997. http://dx.doi.org/10.1016/j.sbspro.2009.01.177

Kramarae, C. (1981). Women and Men Speaking. Rowley, MA: Newbury House.

Kyungsim, H. N., \& Leavell, A. G. (2006). Language learning strategy use of EFL students in an intensive English learning context. System, 34(3), 399-415. http://dx.doi.org/10.1016/j.system.2006.02.002

Lee, K. R., \& Oxford, R. (2008). Understanding EFL learners' strategy use and strategy awareness. The Asian EFL Journal, 10(1), 7-32.

Li, J., \& Qin, X. (2006). Language learning styles and learning strategies of tertiary-level English learners in China. RELC Journal, 37(1), 67-90. http://dx.doi.org/10.1177/0033688206063475

Li, S. Q., \& Zhang, Y. (2009). Languge learning strategy use by extroverted or introverted English majors with high language proficiency. Crazy English Teachers, 7, 35-37, 41.

Liyanage, I. J. B. (2004). An exploration of language learning strategies and learner variables of Sri Lankan learners of English as a second language with special reference to their personality types (Unpublished doctoral dissertation). Griffith University, Queensland, Australia.

Magogwe, J. M., \& Oliver, R. (2007). The relationship between language learning strategies, proficiency, age and self-efficacy beliefs: A study of language learners in Botswana. System, 35, 338-352. http://dx.doi.org/10.1016/j.system.2007.01.003

Maubach, A.-M., \& Morgan, C. (2001). The relationship between gender and learning styles amongst A level modern languages students. Language Learning Journal, 23, 41-47. http://dx.doi.org/10.1080/0957173018 5200081

Myers, I. B., \& McCaulley, M. H. (1985). Manual: A Guide to the Development and Use of the Myers-Briggs Type Indicator. Palo Alto, CA: Consulting Psychological Press (CPP), Inc.

Myers, I. B., \& Myers, P. B. (1980). Gifts Differing: Understanding Personality Type. Palo Alto: CPP Books.

Naiman, N., Fröhlich, M., Stern, H. H., \& Todesco, A. (1978). The good language learner research. In Education Series 7. Toronto, ON: Ontario Institute for Studies in Education.

Ok, L. K. (2003). The Relationship of school year, sex and proficiency on the use of learning strategies in learing English of Korean junior high school students. Asian EFL Journal, 5(3), 1-36. 
Oxford, R. L. (1990). Language Learning Strategies: What Every Teacher should Know. Newbury House/Harper Collins, NY.

Oxford, R. L. (1990). Language learning strategies: What every teacher should know (pp. 1-22). Newbury House/Harper Collins, NY.

Oxford, R. L. (1995). Language Learning Strategies around the World: Cross-Cultural Perspectives. National Foreign Language Center Technical Reports Series, No. 13. University of Hawaii Press.

Oxford, R. L. (2011). Teaching and Researching Language Learning Strategies. Great Britain: Pearson Education Limited.

Oxford, R. L., \& Ehrman, M. (1995). Adult's language learning strategies in an intensive foreign language program in the United States. System, 23(3), 359-386. http://dx.doi.org/10.1016/0346-251X(95)00023-D

Oxford, R., \& Nyikos, M. (1989). Variables affecting choice of language learning strategies by university students. The Modern Language Journal, 73(iii), 291-300. http://dx.doi.org/10.1111/j.1540-4781.1989. tb06367.x

Oxford, R., \& Nyikos, M. (1989). Variables Affecting Choice of Language Learning Strategies by University Students. The Modern Language Journal, 73(3), 291-300. http://dx.doi.org/10.1111/j.1540-4781.1989. tb06367.x

Oxford, R., Nyikos, M., \& Ehrman, M. (1988) Vive la difference? Reflections on sex differences in use of language learning strategies. Foreign Language Annals, 21(4), 321-329. http://dx.doi.org/10.1111/j.19449720.1988.tb01076.x

Radwan, A. A. (2011). Effects of L2 proficiency and gender on choice of language learning strategies by university students majoring in English. Asian EFL Journal, 13(1), 114-162.

Radwan, A. A. (2011). Effects of L2 proficiency and gender on choice of language learning strategies by university students majoring in English. Asian EFL Journal, 13(1), 114-162.

Rahimi, M., Riazi, A., \& Saif, S. (2011). An investigation into the factors affecting the use of language learning strategies by Persian EFL learners. Canadian Journal of Applied Linguistics, 31-60.

Rao, Z. H. (2008). Individual differences and cltural factors in English learning strategies. Shanghai: Shanghai Foreign Language Education Press.

Rao, Z. H. (2008). Individual differences and cultural factors in English learning strategies. Shanghai: Shanghai Foreign Language Education Press.

Rubin, J. (1975). What the 'good language learner' can teach us. TESOL Quarterly, 9(1), 41-51. http://dx.doi.org/10.2307/3586011

Sharp, A. (2008). Personality and second language learning. Asian Social Science, 4, 17-25.

Sharp, A. (2008). Personality and second language learning. Asian Social Science, 4, 17-25.

Sheorey, R. (1999). An examination of language learning strategy use in the setting of an indigenized variety of English. System, 27(2), 173-190. http://dx.doi.org/10.1016/S0346-251X(99)00015-9

Skehan, P. (1989). Individual differences in second language learning. London: Edward Arnold.

Stern, H. H. (1975). What can we learn from the good language learner? Canadian Modern Language Review, 34, 304-318.

Wakamoto, N. (2000). Language learning strategy and personality variables: Focusing on extroversion and introversion. IRAL, 38, 71-81. http://dx.doi.org/10.1515/iral.2000.38.1.71

Wen, Q. F. (1995). Differences of strategy use among successful and unsuccessful EFL learners. Foreign Language Teaching and Research, 103(3), 61-66.

Wong, L. L. C., \& Nunan, D. (2011). The learning styles and strategies of effective language learners. System, 39(2), 144-163. http://dx.doi.org/10.1016/j.system.2011.05.004

$\mathrm{Wu}$, Y. L. (2008). Language learning strategies used by students at different proficiency levels. Asian EFL Journal, 10(4), 75-95.

Yang, M. N. (2007). Language learning strategies for junior college students in Taiwan: Investigating ethnicity and proficiency. The Asian EFL Journal, 9(2), 35-57. 
Yang, N. D. (1999). The relationship between EFL learners' beliefs and learning strategy use. System, 27, 515-535. http://dx.doi.org/10.1016/S0346-251X(99)00048-2

Yin, C. (2008). Language learning strategies in relation to attitudes, motivations, and learner beliefs: Investigating learner variables in the context of english as a foreign language in China (Unpublished doctoral dissertation). University of Maryland, College Park.

Yu, Y. F., \& Wang, B. (2009). A study of language learning strategy use in the context of EFL curriculum and pedagogy reform in China. Asia Pacific Journal of Education, 29(4), 457-468. http://dx.doi.org/10.1080/02188790903309041

Zhang, Q. Z. (2004). Effects of tolerance of ambiguity on the selection of language learning strategies. Foreign Language Teaching and Research, 36(6), 457-461.

Zhou, Y. P. (2010). English language learning strategy use by Chinese senior high school students. English Language Teaching, 3(4), 152-158. http://dx.doi.org/10.5539/elt.v3n4p152

\section{Copyrights}

Copyright for this article is retained by the author(s), with first publication rights granted to the journal.

This is an open-access article distributed under the terms and conditions of the Creative Commons Attribution license (http://creativecommons.org/licenses/by/3.0/). 